Doi: $10.30868 /$ ad.v4i02.798

\title{
THE INFLUENCE OF ISLAMIC COMMERCIAL BANK'S \\ LETTER OF CREDIT FINANCING AND EXCHANGE RATE TOWARDS INDONESIA'S EXPORTS FROM 2014 TO 2018
}

\section{PENGARUH SUKUK, NILAI TUKAR TERHADAP EKPOR INDONESIA TAHUN 2014-2018}

\author{
Andi Triyawan', Amalia Syafira Novitasari ${ }^{2}$ \\ ${ }^{1,2}$ Fakultas Ekonomi dan Manajemen, Universitas Darussalam Gontor \\ andisurabaya85@gmail.com \\ amaliasyafira@gontor.ac.id
}

\begin{abstract}
International trade activities become one of the important factors in economic growth. Compared to the implementation of domestic trade, international trade is much more complex. Thus, it is certain that both will be in trouble paying if the buyer has no foreign exchange (means of payment). Based on the above background the researcher presents financing through Islamic Commercial Banks. Besides, it is supported by additional economic variables named the exchange rate. The method used descriptive quantitative with secondary data collection techniques scattered on Central Statistics Agency (BPS) reports, Bank Indonesia (BI), and Financial Services Authority (OJK). The data analysis technique is Multiple Linear Regression based on OLS (Ordinary Least Square). The results of this research, that 1) Islamic Commercial Bank Letter of Credit (L/C) financing influnced exports by $10 \%$ and $90 \%$ influenced by other variables 2) Exchange rates influenced of 2\% and the remaining 98\% influenced by other variables 3) Letter of Credit (L/C) Financing Islamic Commercial Banks and foreign exchange rates can explain their influenced on export value by $21 \%$ while the remaining $79 \%$ are influenced by other variables.
\end{abstract}

Keywords: $L / C$ financing, exchange rates, export

\begin{abstract}
ABSTRAK
Kegiatan perdagangan internasional menjadi salah satu faktor penting dalam pertumbuhan ekonomi. Dibanding dengan pelaksanaan perdagangan dalam negeri, perdagangan internasional sangatlah rumit dan kompleks. Dengan demikian, dapat dipastikan keduanya akan mengalami kesulitan dalam pembayaran apabila pihak pembeli tidak memiliki devisa (alat pembayaran). Berdasarkan latar belakang di atas peneliti menghadirkan pembiayaan melalui Bank Umum Syariah dan ditunjang dengan tambahan variabel ekonomi yakni kurs. Metode yang digunakan ialah deskriptif kuantitatif dengan teknik pengumpulan data sekunder yang tersebar pada laporan (Badan Pusat Statistik (BPS), Bank Indonesia (BI), serta Otoritas Jasa Keuangan (OJK). Teknik analisis datanya adalah Regresi Linear Berganda yang berbasiskan Ordinary Least Square (OLS). Hasil penelitiannya, bahwa 1) Pembiayaan Letter of Credit (L/C) Bank Umum Syariah berpengaruh terhadap ekspor sebesar 10\% dan sebesar 90\% dipengaruhi oleh variabel lain 2) Kurs berpengaruh sebesar dan sisanya sebesar 2\% dan sebesar 98\% dipengaruhi oleh variabel lain 3) Pembiayaan Letter of Credit (L/C) Bank Umum Syariah dan kurs valuta asing secara bersama-sama dapat menjelaskan pengaruhnya terhadap nilai ekspor sebesar $21 \%$ sedangkan sisanya sebesar $79 \%$ dipengaruhi oleh variabel lain.
\end{abstract}

Kata kunci: pembiayaan letter of credit (L/C), kurs, ekspor 


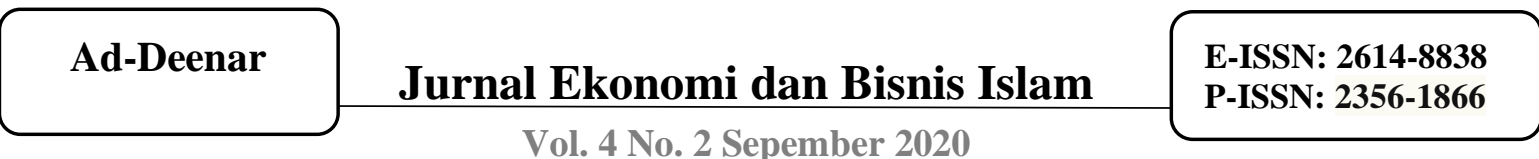

Vol. 4 No. 2 Sepember 2020

\section{A. INTRODUCTION}

International trade activities are an important factor in economic growth (U. Ejiro Osiobe, 2019). There are at least two parties involved in international trade transactions, namely sellers and buyers. The transaction is a practice to sell goods (export) and the transaction to buy other production (import) (Roberto Bergami, 2007; 43). So, if trading (buying and selling) was done it directly, where the sellers and buyers meet and negotiate the types of goods, prices, shipping methods, and payments, then there will be no difficulty in buying and selling.

Compared to the implementation of domestic trade, international trade is much more complex. The complexity such as the distinction between exporters and importers separated both geographically and geopolitically whereas goods must be sent and transported from one country to another through various regulations. In contrast, each country has its own languages, currencies, estimates and scales, legal differences in trade, even exporters and importers do not know one another. Thus, it is certain that both will experience difficulties in payment if the buyer does not have a foreign exchange (means of payment). Other difficulties if the importer has sent payment, the importer will face risks such as the goods purchased are not sent by the exporter, and the exporter has sent the goods, while the importer has not made the payment (Cyrielle Gaglio, 2017; 39). So, to overcome this problem, bank services are needed to facilitate transactions. The system is known as a Letter of Credit (L/C) (Cyrielle Gaglio, 2017; 92).

The factor influencing Indonesian exports are Islamic Commercial Bank L/C financing (HSBC, 2016; 164) and the dollar exchange rate toward the rupiah (Allah Dad and Asif Mehbub Karim, 2019; 57), because the increase in exports in Indonesia is sourced from Islamic Bank L/C murabahah financing (Ahmet Suayb Gundogdu, 2012; 109). In the Sharia Banking Statistics (SPS) of the Financial Services Authority (OJK), the amount of Islamic banking financing in 2018 grew significantly by 202,766 billion rupiahs compared to the previous year's achievement by approxiantely 190,354 billion rupiahs (Data and Statistics Publication Reports" www.ojk.go.id, (Accessed on 2 January 2020, at 20.53 West Indonesia Time). Financing is a $\mathrm{L} / \mathrm{C}$ Islamic Commercial Bank used as an independent variable that influences the acquisition of exports.

Seen from the problem, that the increase in Islamic commercial bank's L/C financing and exchange rates was not followed by the Indonesia's exports increase. Yet, the decline in Islamic Commercial Bank's L/C financing and exchange rates was not followed by the 


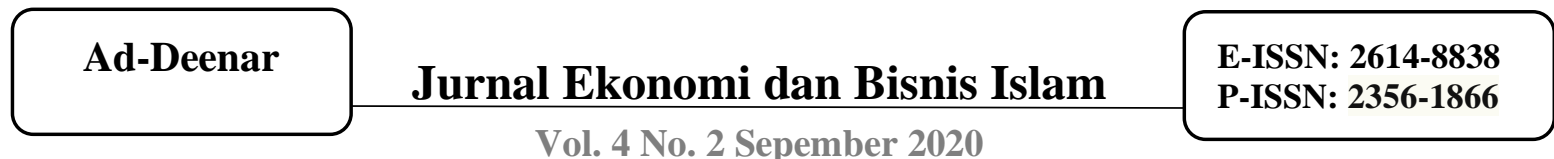

Vol. 4 No. 2 Sepember 2020

Imdonesia's exports decline. So, in this case, there is a mismatch between the data and various theories which states that the higher number of Islamic Commercial Bank's L/C financing and exchange rates show, the higher Indonesia's export rate (Oscar BajoRubio and Burcu Berke, 2018; 27). Furthermore, in practice, Islamic Commercial Bank L/C financing and exchange rates are not always same by the theory. This have become a problem so it is interesting to be examined in this study.

\section{B. RESEARCH METHOD}

The research method used is a quantitative descriptive method, namely the method of data analysis in the form of numbers used to analyze and answer concisely and clearly about the influence and magnitude of the influence of an event and the problems that exist so that conclusions can be drawn. Data from this research method must be collected, presented and analyzed so that it can provide an overview. Numerical and objective data is a characteristic possessed by quantitative research methods. The facts or phenomena observed have an objective reality that can be measured (Carrie Williams, 2007; 65). The data used in this study are secondary data which is primary data that has been processed and presented by primary data collectors or other parties, such as in the form of tables or diagrams (Alexandra Ogbonna Udu Kalu, 2019; 2).

\section{RESULT AND DISCUSSION}

By definition of sharia, trade or sale is the exchange of an asset with assets as a transfer of ownership through mutual ridhai. This definition contains the understanding that covers all forms of exchange, both goods with goods (barter), goods with money (trading with exchange tools), or money with money (currency exchange). Trade can be of two kinds, namely halal trade, which in sharia is called buying and selling, and haram trading which is commonly referred to as usury (Mirza Tabrani and Marlizar, 2018; 24-25).

The exchange rate or often called the prices of foreign currencies. Exchange rates (exchange rates) are exchanges between two different currencies. So, the exchange rate is a comparison between the value of a country's currency with another country or the price of a currency against other currencies. An increase in the exchange rate (exchange rate) of the domestic currency is called appreciation of the currency (foreign currency is cheaper, this means the value of the foreign currency in the country increases) (Nicolas Magud dan Sebastian Sosa, $2010 ; 3)$. A fall in the exchange rate (the exchange rate) is called depreciation of the domestic currency (foreign currency 
becomes more expensive, which means the domestic currency is down) (Nicolas Magud dan Sebastian Sosa, 2010; 3).

Banking is everything related to banks, covering institutions, business activities, as well as ways and processes in carrying out their business activities (Republic of Indonesia Law No. 10 of 1998 concerning Amendments to Law No. 7 of 1992 concerning Banking Article 1 Paragraph 1). The bank is a business entity that collects funds and the public in the form of deposits and distributes them to the public in the form of credit and other forms to improve people's lives (Republic of Indonesia Law No. 10 of 1998 concerning Amendments to Law No. 7 of 1992 concerning Banking Article 1 Paragraph 1). Commercial Banks are banks that carry out business activities conventionally and based on Sharia Principles which in their activities provide services in payment traffic (Republic of Indonesia Law No. 10 of 1998 concerning Amendments to Law No. 7 of 1992 concerning Banking Article 1 Paragraph 3).

$\mathrm{L} / \mathrm{C}$ are letters issued by a bank at the request of the importer of the bank's subscription addressed to overseas exporters who are importers' relations giving the exporter the right to withdraw money orders from the concerned importer for a number of the money mentioned in the letter.

\section{International Trade}

Trade based on the scope of its territory can be divided into domestic trade and foreign trade. Domestic trade is a trade transaction that occurs between individuals who have the same citizenship, whether carried out in their own country or another country. Since trade transactions have changed from barter transactions to transactions with money intermediaries, trading activities between individuals within one country and between nations have continued to increase.

There is a difference between domestic and foreign trade. In the Islamic concept, domestic trade does not require interference from the state even direct directions are not needed. The state only conducts general directions, to force individuals to be bound by sharia laws in their trade. The state will impose penalties on traffickers who violate sharia law as they do violators of other mu'amalah transaction activities, such as employment, rent, marriage, and so on.

A country's currency can be exchanged for another country's currency by the prevailing exchange rates on the currency market or what is commonly referred to as the foreign exchange market. The foreign exchange market is an organizational network in which individuals, companies and banks make purchases and sales of 
foreign exchange or foreign exchange (Christopher J. Neely, 2015; 1).

Along with the community's need for the application of sharia principles in business activities, including in international trade, then $\mathrm{L} / \mathrm{C}$ facilities emerged in the world of Islamic banking. The legal provisions concerning the Islamic L/C are guided by the Fatwa of the National Sharia Council of the Indonesian Ulema Council (DSN MUI) No. 34 and 35 of 2002 concerning Islamic Import and Export L/C (Republic of Indonesia Law No. 10 of 1998 concerning Amendments to Law No. 7 of 1992 concerning Banking Article 1 Paragraph 1).

Agreement or agreement (contract) in the terminology of Islamic law is one way to obtain property that is widely used in everyday life. The contract comes from the Arabic "Al-Aqdun" or in the plural called "Al Uqud" which means bond or knots. The definition of a contract in the terminology of fiqh law is an agreement between consent (offer) and qabul (recipient) which establishes the pleasure of the parties.

With the existence of a contract, the parties are bound by the provisions of Islamic law whose rights and fulfillment of their obligations must be realized. Another characteristic, which distinguishes between conventional banks and Islamic banks is that Islamic banks use the principle of business not based on interest, but based on the principle of profit-sharing, buying and selling or leasing.

In this case, time-series data is collected and used by the author. Time series data or time-series data is a collection of data from a certain phenomenon that is obtained at a certain time (Ajla Kirlić and Muhedin Hadžić, 2017; 2), such as a bank financing balance from 2010 to 2015.

To determine the purpose of this study is to determine how much influence the Islamic Commercial Bank L/C Financing and the exchange rate on Indonesian exports in 2014-2018, then the multiple linear regression analysis tools are used by the author in processing the data using an application (software), namely E-views 7 (Econometric Views).

\section{a. Normality Test}

The test to determine whether the dependent variable, independent or both are normally distributed, close to normal or not. A good regression model should have a normal or near-normal distribution. Detect whether the data is normally distributed or cannot be known by describing the spread of data through a graph. If the data spread around the diagonal line and follows the direction of the diagonal line, the regression model meets the normality assumption. Based on the normality test by using Eviews 7 , the following results are obtained: 


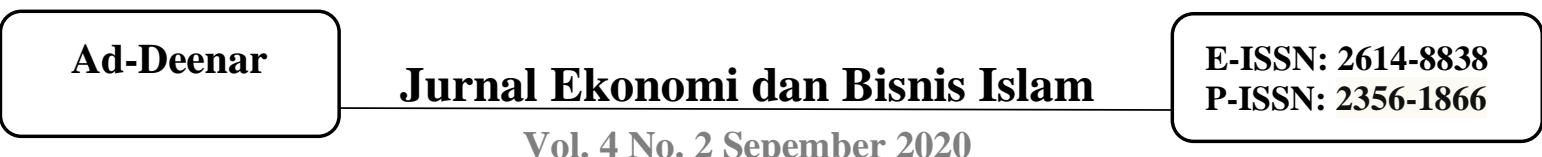

Vol. 4 No. 2 Sepember 2020

Chart 1. Normality: One-Sample JarqueBera Test

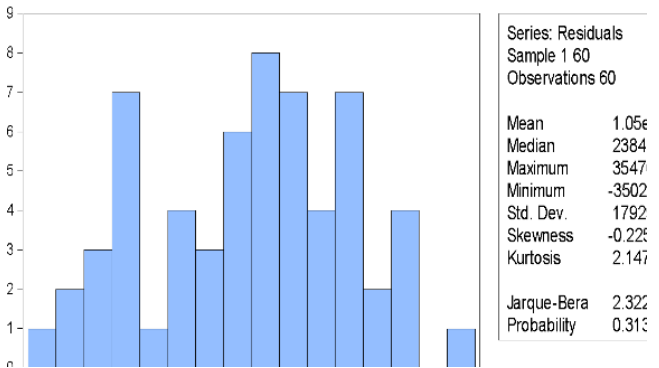

Based on this parameter it is known that the magnitude of the probability value on Jarque-Bera is 0.313098, greater than the value of 0.05 . Thus it can be concluded that the regression model meets normal assumptions.

b. Autocorrelation

Autocorrelation test is performed to find out whether in a linear regression model there is a strong positive or negative relationship between the data that exists in the research variable. To check for autocorrelation using the test DurbinWatson by comparing the DW value. The following autocorrelation test results using the Durbin-Watson Test (DW Test) statistical:

Table 1. Autocorrelation Test

\begin{tabular}{|c|c|c|c|c|}
\hline $\begin{array}{l}\text { M } \\
\text { od } \\
\text { el }\end{array}$ & $\begin{array}{c}\mathrm{R} \\
\text { Squ } \\
\text { are }\end{array}$ & $\begin{array}{c}\text { Adj } \\
\text { uste } \\
\text { d R } \\
\text { Squ } \\
\text { are }\end{array}$ & $\begin{array}{l}\text { Std. } \\
\text { Error of } \\
\text { regressio } \\
\mathrm{n}\end{array}$ & $\begin{array}{l}\text { Dur } \\
\text { bin- } \\
\text { Wat } \\
\text { son }\end{array}$ \\
\hline 1 & $\begin{array}{c}0.6 \\
064 \\
22\end{array}$ & $\begin{array}{c}0.57 \\
779 \\
8\end{array}$ & $\begin{array}{c}11649.7 \\
7\end{array}$ & $\begin{array}{c}0.57 \\
603 \\
5\end{array}$ \\
\hline
\end{tabular}

From the results of the table and figure above, we can find out the results of autocorrelation testing using the test Durbin-Watson, the $\mathrm{DW}_{\text {count }}$ value of 0.576035 . The number of data $(\mathrm{N})=60$ and the number of independent variables 2 $(\mathrm{k}=2)$. Then obtained DW count value $(0.576035)$ located before after $d_{1}=$ $0.576035<1.51<1.65$. Then it can be concluded that the positive autocorrelation regression model.

\section{c. Heteroscedasticity Test}

The test is performed to determine whether in a regression model there is an inequality of variance from the residuals of observation to another observation. A good regression model is no heteroscedasticity. The following results of heteroscedasticity testing in this study:

Table 2. ARCH Test

2.3664 Prob.

0.103

F-statistic

$74 \mathrm{~F}(2,57)$

\section{0}

Obs*R- $\quad 4.4000 \quad$ Prob. Chi- 0.100

squared 86 Square(2) 3

Based on the table above, the significance value is 0.1003 , the value is greater than 0.05 so it can be concluded that the data used in this study do not have heteroscedasticity symptoms. 


\section{d. Multicollinearity Test}

The test aims to test whether the regression model found a correlation between independent variables. A good regression model should not occur the correlation between independent variables. Multikolinearitas following test results:

Table 3. Multicollinearity Test

\begin{tabular}{cccc}
\hline \hline \multicolumn{5}{c}{ Coeffi Uncentere } \\
cient & $d$ & Centered \\
Varian & & \\
Variable & ce & VIF & VIF \\
& & & \\
\hline \multicolumn{5}{c}{10392} & & \\
C & 6.9 & -0.437379 & NA \\
& 44.92 & 1.00000 \\
X1 & 261 & -0.437379 & 0 \\
& \multicolumn{4}{c}{1.00000} \\
& 0.2288 & 0 \\
X2 & 53 & -0.437379 & 0 \\
\hline \hline
\end{tabular}

Based on the above table, it can be seen that all the independent variables VIF $<10$ Then, it can be seen that the VIF value in the $\mathrm{X}$ variable is -0.437379 . So it can be concluded that in the regression equation model there is no multicollinearity or can be said to be free from multicollinearity and the data can be used for research.

$$
\text { e. T-Test }
$$

T-test shows how far the influence of one explanatory or independent variable individually in explaining the dependent variable by assuming the other independent variables are constant. To find out the $t_{\text {table }}$ value is $t_{\text {table }}=($ level of confidence divided by 2 ; the number of observations minus number of independent variables minus 2), if written in the form of formula $t_{\text {table }}=\alpha / 2$; nk-2. The following are the results of the $t-$ test, are:

Table 4. Result of T-Test

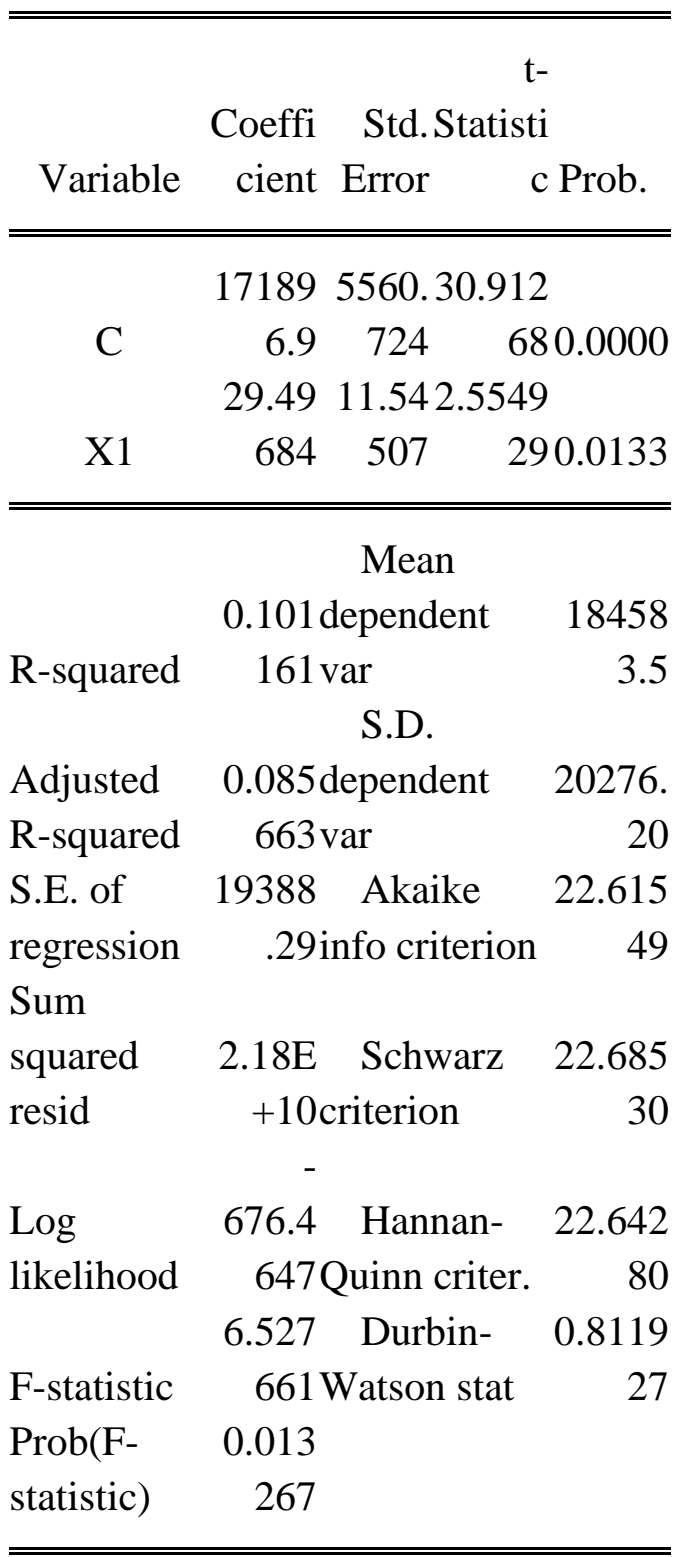

From the results of the calculations in the table above, it can be seen that the value 
variable financing L/C Islamic Commercial Bank amounted to 0.0005 , while the $t_{\text {table }}$ value obtained from the $\mathrm{t}$ distribution sought at the $5 \%$ significance $(0.05): 2=5 \%$ or 0:05. (Two way test) degrees of freedom (df) $n k-1$ or $60-2-1=57$, we get $t_{\text {table }}$ of 1.672. Therefore, the value of $t_{\text {count }}$ is smaller than the value of $\mathrm{t}_{\text {table }}\left(\mathrm{t}_{\text {count }}<\mathrm{t}_{\text {table }}=\right.$ $0.0005<1,672)$. Then, Ho1 accepted and $\mathrm{Ha}_{1}$ rejected. As for the value variable exchange rate 0.0050 is smaller than $t_{\text {table }}<$ $\left.\mathrm{t}_{\text {table }}=0.0050<1,672\right)$. Then $\mathrm{Ho}_{2}$ accepted, and $\mathrm{Ha}_{2}$ rejected. Thus, it can be concluded that partially Islamic Commercial Bank L/C financing variables and foreign exchange rates have a significant influence on Indonesia's export.

\section{f. F-Test}

The F-test shows whether all the independent variables entered in the model have a joint or simultaneous influence on the dependent variable. Based on the table above, the $F_{\text {count }}$ value is 0.000901 with a significance level of 0.05 . The $F_{\text {count }}$ value < $F_{\text {table }}(0.000901<3.16)$ with the value of $\mathrm{F}_{\text {table }} \mathrm{df} \alpha,(\mathrm{k}),(\mathrm{n}-\mathrm{k})$ or $0.05,(2),(60-2)=58$ $=3.16$. So it can be concluded that the financing of Islamic Commercial Bank L/C and foreign exchange rates simultaneously have a significant influence on the value of exports.

\section{g. Correlation Coefficient Test (R)}

The correlation coefficient shows the ability of the relationship between independent variables with the dependent variable. The correlation coefficient produced in this test is useful to show the strength of the relationship between the independent variable and the dependent variable. Following:

Table 5. Correlation Coefficient Test Model I

\begin{tabular}{|c|c|c|}
\hline & $\mathrm{X} 1$ & $\mathrm{Y}$ \\
\hline $\mathrm{X} 1$ & 1.000000 & 0.318058 \\
\hline $\mathrm{Y}$ & 0.318058 & 1.000000 \\
\hline
\end{tabular}

Based on the above table, the correlation coefficient of 0.318058 is located at the coefficient interval of 0.20 0.399, which means the level of relationship between L/C financing of Islamic Banks to Indonesian exports is low.

Table 6. Correlation Coefficient Test Model II

\begin{tabular}{|c|c|c|}
\hline & $\mathrm{X} 1$ & $\mathrm{Y}$ \\
\hline $\mathrm{X} 1$ & 1.000000 & 0.168431 \\
\hline $\mathrm{Y}$ & 0.168431 & 1.000000 \\
\hline
\end{tabular}

Based on the above table, the correlation coefficient of 0.168431 is located at the interval coefficient of 0.00 0.199 , which means that the level of the relationship between foreign exchange rates and the acquisition of Indonesian exports is very low.

h. Table 7. Correlation Coefficient Test Model III 


\begin{tabular}{|c|c|c|c|}
\hline \multicolumn{3}{|c|}{ Ad-Deenar } & Iurnal Fke \\
\hline & $\mathrm{X} 1$ & $\mathrm{X} 2$ & $Y$ \\
\hline $\mathrm{X} 1$ & $\begin{array}{c}1.000 \\
000\end{array}$ & $\begin{array}{c}- \\
0.437 \\
379\end{array}$ & 0.318058 \\
\hline $\mathrm{X} 2$ & $\begin{array}{c}- \\
0.437 \\
379\end{array}$ & $\begin{array}{c}1.000 \\
000\end{array}$ & 0.168431 \\
\hline $\mathrm{Y}$ & $\begin{array}{c}0.318 \\
058\end{array}$ & $\begin{array}{c}0.168 \\
431\end{array}$ & 1.000000 \\
\hline
\end{tabular}

Based on the table above, a correlation coefficient of -0.437379 is obtained which means that individually the relationship level is weak inversely

h. Test of The coefficient of determination (R2)

The coefficient of determination used to determine how much the ability of independent variables to explain the dependent variable. Based on testing the coefficient of determination using E-views obtained the following output:

Table 8. Determination Coefficient Test Model I

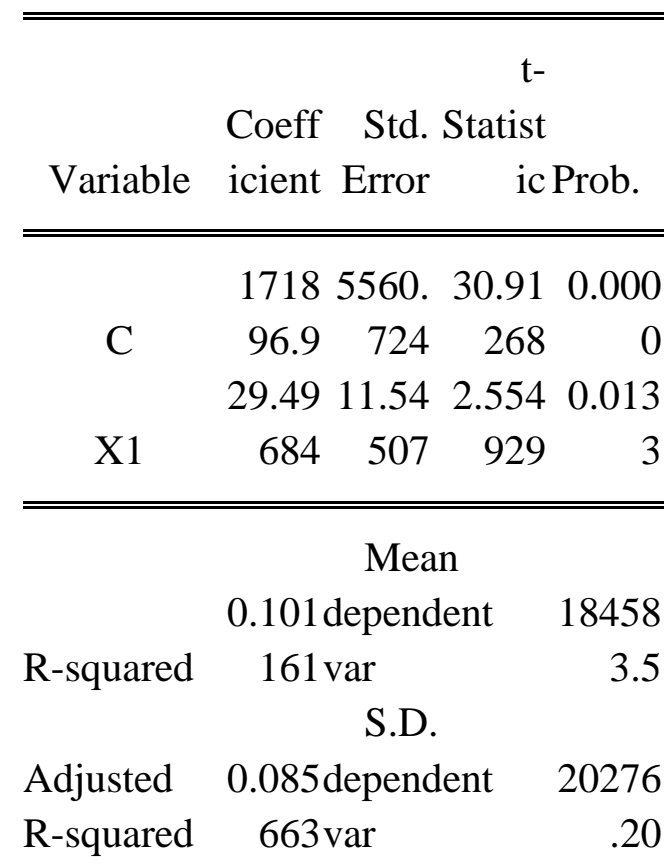

\begin{tabular}{lrrr} 
S.E. of & $1938 \quad$ Akaike & 22.61 \\
regression & 8.29info criterion & 549 \\
Sum & \multicolumn{3}{c}{} \\
squared & $2.18 \mathrm{E} \quad$ Schwarz & 22.68 \\
resid & +10 criterion & 530 \\
& - & \\
Log & $676.4 \quad$ Hannan- & 22.64 \\
likelihood & 647 Quinn criter. & 280 \\
& $6.527 \quad$ Durbin- & 0.811 \\
F-statistic & 661 Watson stat & 927 \\
Prob(F- & 0.013 & \\
statistic) & 267 & \\
\hline \hline
\end{tabular}

Based on the results of the table data above, we can find out the R-Squared determination coefficient value is 0.101161 or about $10 \%$. So it can be concluded that this figure can explain the influence of Islamic Commercial Bank L/C financing on Indonesian exports by $10 \%$, while the remaining $90 \%(100 \%-10 \%=90 \%)$ is influenced by other variables.

Table 9. Determination Coefficient Test Model II

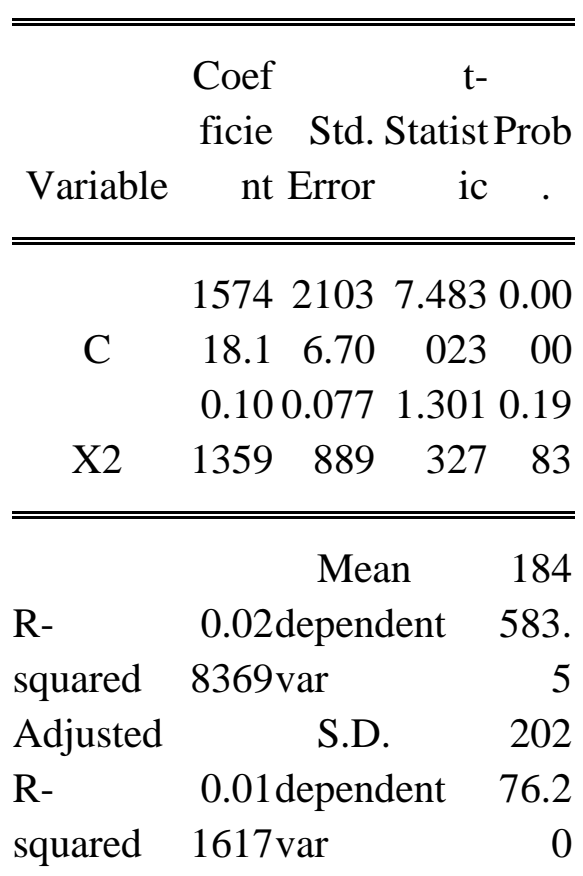




\begin{tabular}{|c|c|c|}
\hline $\begin{array}{l}\text { S.E. of } \\
\text { regressio }\end{array}$ & $\begin{array}{l}\text { Akaike } \\
\text { 2015info }\end{array}$ & $\begin{array}{r}22.6 \\
933\end{array}$ \\
\hline $\mathrm{n}$ & 8.08 criterion & \\
\hline Sum & & 22.7 \\
\hline squared & 2.36 Schwarz & 631 \\
\hline resid & $E+10$ criterion & 7 \\
\hline & - Hannan- & 22. \\
\hline $\log$ & 678.Quinn & 206 \\
\hline \multicolumn{2}{|c|}{ likelihood 8009criter. } & \\
\hline & 1.69 Durbin- & 79 \\
\hline F-statistic & 3453Watson stat & \\
\hline $\operatorname{Prob}(\mathrm{F}-$ & 0.19 & \\
\hline statistic) & 8292 & \\
\hline
\end{tabular}

Based on the results of the above table data, it can be seen the value of the RSquared determination coefficient is 0.028369 or about $2 \%$. So it can be concluded that this number means that the foreign exchange rate can explain the effect individually on the export value of $2 \%$ while the remaining $98 \%(100 \%-2 \%=$ $98 \%$ ) is influenced by other variables.

Table 10. Determination Coefficient Test Model III

\begin{tabular}{|c|c|c|}
\hline \multicolumn{2}{|c|}{$\begin{array}{c}\text { Varia cie } \\
\text { ble } \text { nt } \text { Stat } \\
\text { blistic }\end{array}$} & Prob. \\
\hline \multicolumn{3}{|c|}{1032384.3} \\
\hline \multicolumn{3}{|c|}{92658.560} \\
\hline \multirow[t]{3}{*}{$\mathrm{C}$} & $\begin{array}{lll}.9 & 26 & 12\end{array}$ & 0.0001 \\
\hline & 44. 12. 3.7 & \\
\hline & 922078192 & \\
\hline \multirow[t]{3}{*}{$\mathrm{X} 1$} & $\begin{array}{lll}61 & 40 & 51\end{array}$ & 0.0005 \\
\hline & $\begin{array}{llll}0.2 & 0.0 & 2.9\end{array}$ & \\
\hline & 288783199 & \\
\hline $\mathrm{X} 2$ & $\begin{array}{lll}53 & 75 & 76\end{array}$ & 0.0050 \\
\hline
\end{tabular}

R- $\quad 0.2$ Mean

square 181 depende

d 17nt var

184583.5

Adjust

ed R- 0.1 S.D.

square 906depende

d $\quad 83 n t$ var $\quad 20276.20$

S.E.

of 182 Akaik

regres 40.e info

sion 88 criterion

22.50943

Sum 1.9

square $0 \mathrm{E}$ Schw

d +1 arz

resid 0criterion 22.61414

- Hann

Log 672an-

likelih .28Quinn

ood 28criter.

22.55039

Durbi

F- 7.9n-

statisti 504Watson

c $\quad 85$ stat

0.576035

Prob(

F- $\quad 0.0$

statisti 009

c) 01

Based on the results of the above data, it can be seen that the coefficient of determination of R-Squared is 0.218117 or around $21 \%$. So it can be concluded that the figure means that the Islamic Commercial Bank L/C financing and foreign exchange rates together can explain its influence on the export value of $21 \%$ while the remaining $79 \%(100 \%-21 \%=79 \%)$ are influenced by other variables. 


\section{CONCLUSION}

This study aims to determine the influence of Islamic Commercial Bank L/C financing and foreign exchange rates in Indonesia for the 2014-2018 period. Data analysis has been done can be concluded as follows.

Based on the $t$ count value for the variable financing $\mathrm{L} / \mathrm{C}, 0.0005$ Islamic Banks are smaller than ttable $(0.0005<$ 1,672) with a significance level of 0.05 . Then Ho accepted and Ha rejected, in other words, the variable financing L/C Islamic Banks have a significant influence on Indonesian exports. While the correlation coefficient value obtained at 0.318058 lies in the coefficient interval $0.20-0.399$ which means the Influence of Islamic Commercial Bank L/C Financing on Indonesian Exports is low. And the coefficient of determination of the R-Squared is 0.101161 or about $10 \%$. So it can be concluded that the figure can explain the influence of Islamic Commercial Bank L/C Financing on Indonesian exports by $10 \%$ while the remaining $90 \%(100 \%-10 \%=90 \%)$ is influenced by other variables not present in this study.

Based on the tcount value for the variable exchange rate is 0.0050 less than ttable (tcount $<$ ttable $=0.0050<0.05$ ) with significance level of 0.05 . Then $\mathrm{Ho} 2$ rejected and $\mathrm{Ha} 2$ accepted, in other words, individual foreign exchange rates have a significant influence on the value of exports. And the correlation coefficient value obtained at 0.168431 is located at the coefficient interval of $0.00-0.199$, which means that individually the level of relationship between exchange rate and export value is very low. Moreover the coefficient of determination of the RSquared is 0.028369 or about $2 \%$. So it can be concluded that this number means that the foreign exchange rate can explain the influence individually on the export value of $2 \%$ while the remaining $98 \%$ (100\% - $2 \%$ $=98 \%)$ is influenced by other variables.

Based on the Fcount value of 0,000901 with a significance level of 0.05 then Ho accepted and Ha rejected, the Fcount value $<$ Ftable $(0,000901<3.16)$. So it can be concluded that Islamic Commercial Bank $\mathrm{L} / \mathrm{C}$ financing and foreign exchange rates simultaneously have a significant influence on the value of exports. So it can be concluded that Islamic Commercial Bank L/C financing and foreign exchange rates simultaneously have a significant influence on export value. With a correlation coefficient of -0.437379 which means that together the level of relationship between $\mathrm{L} / \mathrm{C}$ financing of Islamic Commercial Banks and foreign exchange rates to the value of Indonesian exports is weak. And the coefficient of determination of the R- 


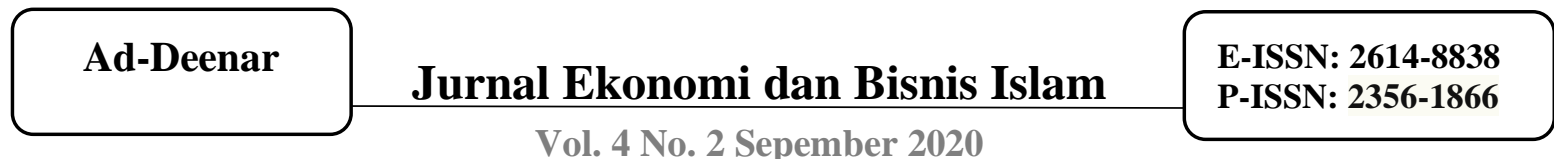

Squared is 0.218117 or about $21 \%$. So it can

be concluded that this figure means the $\mathrm{L} / \mathrm{C}$ financing of Islamic Commercial Banks and foreign exchange rates together can explain its influence on the export value of $21 \%$ while the remaining $79 \%$ is influenced by other variables.

From the results of this study, it can be analyzed and concluded that in obtaining a high export value and increasing every year, the Islamic banks and Indonesian banks must increase the distribution of financing to customers, especially L/C financing.

\section{BIBLIOGRAPHY}

Osiobe, U. Ejiro. (2019). A Literature Review of Human Capital and Economic Growth. Business and Economic Research, 9 (4).

Bergami, Roberto. (2007). Will the UCP Provide Solutions to Letters of Credit Transactions?. The International Review of Business Research Papers, 3 (2).

Gaglio, Cyrielle. (2017). Trade Liberalization and Export Performance: A Literature Review", the Revue d'Economie Politique, Vol. 1.

HSBC. (2016). Rethinking Trade and Finance. Paris: ICC.

Dad, Allah and Asif Mehbub Karim. (2019). A Literature Review on External Affecting Export Competitiveness of the Raw Woven Sector of Pakistan". The Malaysian Journal of Social Sciences and Humanities. 4 (2).

Gundogdu, Ahmet Suayb. (2012). The Rise of Islamic Finance: 2-Step Murabaha", the Asia-Pacific Management Accounting Journal, Vol. 13(1).
"Data and Statistics Publication Reports" www.ojk.go.id, (Accessed on 2 January 2020, at 20.53 West Indonesia Time).

Rubio, Oscar Bajo and Burcu Berke, (2018). International Trade and Finance: A Review", Revista De Economia Mundial.

Williams. Carrie. (2007). Research Methods. The Journal of Business and Economic Research, 5(3).

Kalu, Alexandra Ogbonna Udu. (2019). "Accessing Secondary Data: A Literature Review".

Tabrani, Mirza and Marlizar. (2018). The Marketing Concept in Islamic Perspective: A Literature Review.

Ozturk, Ilhan. (2006). Exchange Rate Volatility and Trade: A Literature Survey. International Journal of Applied Econometrics and Quantitative Studies, 3(1).

Magud, Nicolas and Sebastian Sosa, (2013). When and Why About Real Exchange Rate Appreciation? The Missing Link between Dutch Disease and Growth", IMF Working Paper.

Republic of Indonesia Law No. 10 of 1998 concerning Amendments to Law No. 7 of 1992 concerning Banking Article 1 Paragraph 1.

Neely, Christopher J. (2015). An Analysis of Recent Studies of the Effect of Foreign Exchange Intervention. SSRN Electronic Journal.

Republic of Indonesia Law No. 10 of 1998 concerning Amendments to Law No. 7 of 1992 concerning Banking Article 1 Paragraph 1.

Kirlić, Ajla and Muhedin Hadžić. (2017). Big Data and Time Series: A Literature review paper. 